\title{
Constructive Arrest: An Analysis of the Case of PP v Mohd Safwan Husain
}

\author{
Muhamad Helmi Md Said ${ }^{1}$, Sahanah Kathirvelu ${ }^{1}$, Lim Jia Min ${ }^{1}$, Nur Aryannie Abd Rahim ${ }^{1}$, Nur Wafda Asyrani \\ Jamaie $^{1}$, Iman Camelia Abdullah Firuz ${ }^{1} \&$ Zulkarnain Abdullah $^{1}$ \\ ${ }^{1}$ Faculty of Law, Universiti Kebangsaan Malaysia, Malaysia \\ Correspondence: Muhamad Helmi Md Said, Faculty of Law, Universiti Kebangsaan Malaysia, 43600 Bandar Baru \\ Bangi, Selangor, Malaysia. Tel: 03-8921-6375.E-mail: mhelmisaid@ukm.edu.my
}

Received: September 16, 2020

Accepted: November 3, 2020

Online Published: December 13, 2020

doi:10.5539/jpl.v14n1p73

URL: https://doi.org/10.5539/jpl.v14n1p73

\begin{abstract}
After the landmark principle in Shaaban \& Ors v. Chong Fook Kam \& Anor that established a different set of definition for arrest in Malaysia Criminal Procedure Law in 1969, the case of Pendakwa Raya lwn. Mohd Safwan Husain again stirred the definition of arrest in the year of 2017. While it has long been a norm in this area of law to differentiate arrest into actual and constructive arrest, the judgment of Mohd Safwan Husain commented the differentiation critically. This paper aims to analyse the arrest happened in the case of Mohd Safwan Husain thoroughly, not only from the perspective of Criminal Procedure Code, but also from the view of Dangerous Drugs Act. Research method used are library research and case analysis. As for now there is no governing law on constructive arrest, the researchers believe that an explanation should be provided on what constitutes a constructive arrest in the Criminal Procedure Code and the present existing provision which is Section 15 Criminal Procedure Code should be amended.
\end{abstract}

Keywords: arrest, actual arrest, constructive arrest, Dangerous Drugs Act 1952

\section{Introduction}

Pendakwa Raya lwn. Mohd Safwan Husain [2017] 7 CLJ 685 is a case decided in the Court of Appeal. A Narcotics Sub-Inspector, SP2, acting on an information on abuse of dangerous drugs, visited Kuala Perlis Police Station, where the respondent was on duty. Upon arrival, SP2 introduced himself and informed the respondent that he was suspected of being involved in drug addiction and required him to carry out a screening test of his urine. The respondent contended that the taking of the his urine sample went against the provision of s. 31A (1) of the Dangerous Drugs Act 1952 (hereinafter referred to as "DDA 1952") because when he was ordered to providethe urine specimen, he was not 'an arrested person' under s. 31A(1) of the DDA 1952 (S. 31A of the DDA empowers the enforcement agency to refer the arrested person to medical officer to make such examination in order to ascertain the facts which may afford evidence to establish the offence under DDA). The learned Judicial Commissioner, delivered the judgment that the meaning of 'arrest' under s.31A of the DDA 1952 does not include constructive arrest. Hence, the prosecution appealed to the Court of Appeal on the issue of whether the meaning of 'an arrested person' in s.31A (1A) of the DDA 1952 includes the concept of constructive arrest.

The Appellate Court agreed with the case of PP lwn. Abdul Rahim Kalandari Mustan[1998] 5 CLJ 566 which held that the splitting of the meaning of arrest is unfortunate as the law only mentions 'arrest'. The sole issue that has to be determined is whether there arises an arrest in Safwan's case regardless under the Criminal Procedure Code or Dangerous Drugs Act 1952. The determination of the issue depends on the facts and circumstances of each case. In this vein, the concept of constructive arrest is applicable for s. 31A of the DDA 1952, as long as the facts and circumstances portrayed that the condition of arrest is fulfilled. Therefore, the arrest of the respondent had been made when his urine sample was taken for the purpose of examination under s. 31A of the DDA 1952. The arrest was made based on the information pertaining to an offence under the DDA 1952 committed by the respondent. He was compelled to provide his urine sample in the toilet of the police station. After the screening test, he was brought to IPK Perlis for further action. Although the respondent was said to have cooperated, and was a support police officer, his freedom was curtailed and he was forced to do as ordered by SP2 ([2017] 7 CLJ 685, 696-701). 
The following part of this paper explains briefly the law of arrest practiced in Malaysia and thereafter analyzes the judgment in Mohd Safwan Husain critically based on the law of arrest.

\section{Research Objectives}

a) To identify the type of arrest stipulated under Malaysia Criminal Procedure Code and under the common law principle.

b) To identify the distinction(s) between actual arrest and constructive arrest.

c) To analyze the concept of constructive arrest in drug cases.

d) To analyze the concept of constructive arrest in the case of Pendakwa Raya lwn Mohd Safwan Husain [2017] 7 CLJ 685.

\section{Research Methodology}

The method used in this research paper is the qualitative method in which the researchers focus on gathering information through thorough research to answer each of the research objectives. One of the methods used is library research. The researchers collect required data and information from textbooks, articles, journal, and academic papers; and summarize the relevant information according to the research objectives. The second method is case analysis. The researchers gathered all cases on arrest from the research platforms such as Lexis Advance, Lexis Academic and Current Law Journal. The researchers then analyze the cases and scrutinize the principles used by the court while deciding the case. The researchers also compare the principles formulated in the older cases with the newer cases. In the case analysis, higher focus is paid on cases on constructive arrest than that of actual arrest. The researchers then look into the cases that discuss about the concept of constructive arrest in drug cases. After all, the discussion converges on the concept of constructive arrest took place in Pendakwa Raya lwn Mohd Safwan Husain [2017] CLJ 7685.

\section{Discussion}

\subsection{Definition of Arrest}

Arrest is defined in Oxford Dictionary of Law as the apprehension of a person suspected of criminal activities (Oxford Dictionary of Law, 2015). A person who is suspected for committing a criminal offence will be caught by an authority. When the person is arrested by the legal authority, there will be a deprivation of personal liberty against the arrested person (Datuk Baljit Singh Sidhu, 2015). In Yong Moi Sin v Kerajaan Malaysia \& Anor [2000] 1 MLJ 35, Abdul Malik Ishak J referred to the case of Spicer $v$ Holt [1976] RTR 389 regarding the word "arrest" and stated that arrest is an ordinary word and to determine whether a person has been arrested, the court should look at whether the arrested person has been deprived of the liberty to go anywhere he wants. Black's Law Dictionary defined arrest as to keep a person in lawful custody (Black's Law Dictionary Website, 2019). Under Malaysian criminal law, the definition of arrest was not mentioned in Penal Code or Criminal Procedure Code (hereinafter referred as "CPC"). However, section 15(1) of the CPC does list out the mode of arrest:

15. Arrest, how made:

(1) In making an arrest the police officer or other person making the same shall actually touch or confine the body of the person to be arrested unless there is a submission to the custody by word or action.

Under this section, the CPC recognises three ways to effect an arrest which are by touch, confinement of the body of the person or submission to the custody either by word or action. Lim Beng Choon J in the case of PP v Johari Abdul Kadir[1987] CLJ Rep 889 described that in making an arrest, the arresting officer can either state that he is arresting the suspected person and it can be done by touching him or confining him ([1987] CLJ Rep 889 page 906-907). The mode of arrest used when arresting a person will determine whether the arrest is valid and was done in accordance to the law (Datuk Baljit Singh Sidhu, 2015). Whether there is an arrest is a question of fact and must be determine according to the circumstances of each case (Lee Chong Fook, Habibah Kiprawi, Che Audah Hassan, 2010). This principle was also stated in the case of $R \boldsymbol{v}$ Inwood[1973] 2 ALL E $R \mathbf{~} 645$ where the court held that to determine whether a person has been arrested, the circumstances of the case has to be examined and decided accordingly.

Apart from the mode of arrest established under section 15 of the CPC, Malaysia also recognises the common law arrest (Malaysian Bar, 2019), as established in the case of Shaaban v Choong Fook Kam [1969] 2 MLJ 219. According to Lord Devlin in Privy Council,

"An arrest occurs when a police officer states in terms that he is arresting or when he uses force to restrain the individual concerned. It occurs also when by words or conduct he makes it clear that he will if 
necessary; use force to prevent the individual from going where he may want to go. It does not occur when he stops an individual to make inquiries."

According to the judgment above, arrest under common law arises when: the police officer informs that he will arrest the suspected person; the police officer uses force to restraint the suspected person; or there is conduct or words that he will use force to prevent the suspected person from leaving. These actions show the existence of valid arrest. Arrest does not occur when the authority stopped any suspected person to make any inquiries (Shaaban $\mathrm{v}$ Chong Fook Kam [1969] 2 MLJ 219).

Privy Council in Shaaban case did not discuss section 15(1) of the CPC and did not refer to any local authority to support those three situations which suggested valid arrest. Instead, references were made to several English authorities (Datuk Baljit Singh Sidhu, 2015). For instance, judgment of Parker J in the case of Alderson v Booth [1969] $2 Q B 216$ where the issue was whether the words that the police officer had said to the defendant that " $I$ shall have to ask you to come to the police station for further tests" constituted an arrest or not. This case held that the words were not sufficient and clear words must be used to constitute valid arrest. Arrest can occur by mere words "I arrest you" without touching provided that the defendant submits himself and go to the police officer. Arrest can also take place when any words is used and the defendant is aware that he was under compulsion and he submitted to that compulsion (Parker J in Alderson v Booth [1969] 2 QB 216). Therefore, Shaaban case has actually applied common law concept of valid arrest and does not make any reference to section 15(1) of the CPC. Nevertheless, the principle in Shaaban case was accepted in many Malaysian cases (Jayaraman \& ors v PP [1982] 2 MLJ 306; PP v Lim Hock Boon [2009] 3 MLJ 604; PP v Johari Abdul Kadir [1987] CLJ Rep 889; PP v Shee Chin Wah [1997] 5 CLJ 472; PP v David Ackowuah Bonsu [1998] 7 MLJ 451; Masa AK Nangkai \& ors v Sgt Edwin Nancha \& anor [2005] 1 MLJ 581; Polis Diraja Malaysia v Audrey Keong Mei Cheng [1994] 3 MLJ 296; Pendakwa Raya v Keow Sze Teve [2018] MLJU 1571; PP v Rosyatimah bte Neza \& anor [1989] 1 MLJ 360 \& PP v Abdul Rahim Kalandari Mustan [1998] 5 CLJ 566).

For example, in the case of Jayaraman \& Ors $v$ PP[1982] 2 MLJ 306 the issue in dispute is whether compliance by any person to a request by a police officer not to leave a prescribed place constituted submission to custody by that person within the meaning of section 15 of the CPC? Suffian LP referred to the case of Shaaban in deciding that when the police officer told the applicants to wait and not to leave the temple, it did not constitute an arrest as the police officer was merely stopping them to make enquiries regarding the attack at the temple. The Lord President did not discuss section 15(1) of the CPC but merely quoted the provision in his judgement. Mohd Hishamuddin J in the case of PP v David Ackowuah Bonsu [1998] 7 MLJ 451 held that the accused was not under arrest when he was inspected by the customs officer. In the case of Pendakwa Raya v Keow Sze Teve [2018] MLJU 1571, the accused was arrested at the video game shop. The learned counsel argued that there was an arrest when the police officer asked regarding the keys found in the possession of the accused. In reference to Shaaban, Abdul Wahab JC held that there was no arrest as the police officer only made inquiries to the accused and the accused was not being guarded or controlled by the police officer and he was free to move around. Therefore, it can be seen that it is Shaaban, instead of section 15(1) of the CPC, that is widely used in Malaysian cases to determine the occurrence of arrest.

It is undeniable that different approach is used by the courts to determine the occurrence of arrest, henceforth leading to the categorization of actual arrest and constructive arrest. Constructive arrest occurs when the court makes an inference from the circumstances that there is a submission by the person to the custody of police (Lee Chong Fook, Habibah Kiprawi, Che Audah Hassan, 2010). To construe whether an arrest had occurred, the court will look at the surrounding circumstances to determine whether there was some form of restraint on the movement of the person; whether he was in state of being watched to prevent his escape; or whether it can be implied that his personal liberty had been restraint (Lee Chong Fook, Habibah Kiprawi, Che Audah Hassan, 2010). To determine the occurrence of constructive arrest, the court look at the facts and circumstances of each case. The case of Pendakwa Raya v Kang Ho Soh [1992] 1 MLJ 360 held that the circumstances of the case must be scrutinized to determine the existence of arrest. Shankar J in Kang Ho Soh also held that the distinction between actual arrest and constructive arrest is not helpful.

Thus, an arrest occurs when the incident fulfills the mode of arrest laid down in section 15(1) of the CPC or it satisfies the conditions of valid arrest in the case of Shaaban. Constructive arrest occurs when an accused is said to be restraint from moving freely or being watched and guarded to prevent from escaping. It is important in criminal proceedings to establish whether an arrest had occurred or not because it will determine the admissibility of the statement made during the arrest. In the case where caution is required, it is important to establish whether arrest had taken place. If there is no arrest, no caution is required to be administered and the statement made during 
the arrest is admissible as evidence if it is relevant (Datuk Baljit Singh Sidhu, 2015). Therefore, arrest regardless of actual or constructive must be established to allow the statement made being admissible as an evidence.

\section{Arrest in Drug Cases}

Mode of arrest is particularly noteworthy and fundamental to drug cases as the mode and timing of arrest would determine the necessity of caution and therefore affects the admissibility of the statements given by the arrestee. While the new amendment of section 113 in Criminal Procedure Code had eliminated the requirement for caution before effecting an arrest for offences under the Penal Code, caution is still required for offences under section 37A of the DDA 1952 because the provision was in pari meteria with the old section $113 \mathrm{CPC}$. Thus, it is pertinent to establish whether an arrest had occurred. If there was no arrest, no caution is required and statements made are admissible provided it is relevant. On the contrary, if an arrest had taken place but caution is not administered, statements made after the arrest is inadmissible (Datuk Baljit Singh Sidhu, 2015). However, the view of the court of law is split on the issue of whether the arrest referred to the actual arrest or the constructive arrest (Datuk Baljit Singh Sidhu, 2015).

\subsection{Cases Where Actual Arrest Is Required before Caution Is Administered}

In this category, the court scrutinizes the moment constructive arrest and actual arrest had taken place respectively. The typical norm of drug cases is that the police officer acting on information raided a particular location, communicated with the person presence in that location, found the suspected items and brought the person and item back to the police station. Although the court admitted that constructive arrest had occurred when the police entered and raided the location, the court emphasized that the need for caution statement only arises after an actual arrest had taken place. Below are a few example cases that fall under thiscategory.

In Public Prosecutor v Salleh Bin Saad [1983] 2 MLJ 164, the accused was charged with the offence of drug trafficking. Acting on information, the custom officers raided the accused's house and two sacks were found in the car which were searched. On being questioned by the custom officer, the accused replied that the sacks contained drug. The accused was then arrested and taken to custom office where his statements were duly recorded (Datuk Baljit Singh Sidhu, 2015). The issue in this case was whether the accused's statement made to the custom officers was admissible as no statutory caution was administered. The learned judge had to consider the issue as to whether the accused was under arrest when the statements were made. Syed Agil Barakbah J held that the words, "after his arrest" in section 37A (1) of the DDA 1952 (Section 37A(1) of DDA 1952 is equivalent to the old version of section 113 of CPC) means after actual arrest and not constructive arrest. The learned judge opined that the accused was only under constructive arrest at the time the statements were made. Actual arrest only took place when he was taken in. Thus, it was unnecessary for the custom officer to administer the statutory caution as required to the accused since there was no arrest and hence his statements were admissible.

This case had been followed by Public Prosecutor v Lim Kin Ann[1988] 1 MLJ 401. The accused was charged with drug trafficking and was charged under section 39B(1)(a) of the DDA 1952. Acting on information, the police went to a house and found four persons inside including the accused. The police also recovered three suitcases. On being questioned, the accused replied that two of the briefcases belonged to him. One of these two briefcases had the letters "Lim" stuck on it. When the accused opened it after being ordered, the police found three packets which they suspected to contain drugs. The police then handcuffed the accused and informed all the four occupants that they were under arrest. At the trial, the defence counsel contended that the statement made by the accused admitting ownership of the two briefcases and all other statements uttered by the accused when the contents in the briefcases were examined were inadmissible as evidence under section 37A of the DDA 1952 because no statutory caution was administered. The defence counsel based his contention on the ground that evidence obtained through crossexamination of the policemen involved in the raid revealed that the four occupants of the room would have been prevented from leaving the room if they had attempted to do so and their submission amounted to them being in custody and therefore under arrest (Datuk Baljit Singh Sidhu, 2015). LC Vohrah J in Public Prosecutor v Salleh Bin Saad[1983] 2 MLJ 164 held that at the material time when the statements were made and recorded, a valid arrest had not been taken place thus there was no need for a statutory caution ([1988] 1 MLJ 401, 404). Thus, the accused's statements were admissible asevidence.

Furthermore, in Public Prosecutor v Tan Chye Joo \& Anor [1989] 5 CLJ 566, the two accused persons were charged for drug trafficking under section 39B of the DDA 1952. A police party had entered the premises and found the two accused persons in the hall. Upon searching the house, the police found a biscuit tin in the ceiling. When being questioned as to the contents of the tin, the first accused replied that it contained "ubat Cina". The lid of the tin was then removed and the police found a substance which they believed to be opium. The two accused persons were then placed under arrest. At the trial, the defence counsel argued that the statement of the first accused, 
"ubat Cina" was inadmissible as at the material time, he was already under arrest and no caution was administered under section 37A of the DDA 1952. The defence counsel's contention was based on the fact that the evidence showed that the accused was not free to go as he liked when the search was taking place. Subsequently, Wan Adnan $\mathrm{J}$ held that the accused was arrested only after the discovery of the drugs in the biscuit tin. Hence, the statement, "ubat Cina" was admissible. Although the police said in the trial that the accused was not free to go during the search, it did not mean that the accused was arrested. There was no evidence that he had tried to run. From the judgment of Wan Adnan J in Tan Chye Joo, Datuk Baljit Singh Sidhu submitted that the last observation of the learned judge implies that if the accused had tried to run and the police had tried to stop him, then there would have been an arrest before the discovery of the drugs (Datuk Baljit Singh Sidhu, 2015).

The final example would be the recent case of Public Prosecutorv Tan Chun Cheng \& Anor [2018] 1 LNS 1651. In this case, acting on information received, PW3 lead a team of policemen to ambush a vehicle. PW3 introduced themselves as policemen to the two men (accused) seated inside the front two seats of the car. PW3 administered caution and then questioned the driver whether there is "barang salah" in his possession, which the driver responded "tolonglah Tuan". PW3 repeated the caution and question to the another men and he responded "Ada, bawah seat sini.". Then, a search was conducted in the car and the police found and seized drug underneath the front passenger's seat. Both of the accused were subsequently brought to the police station. The court held that actual arrest only took place when the accused were brought to the police station and there were considered under constructive arrest ([2018] 1 LNS 1651,24). In other words, when both accused gave statements, they were not under arrest. Therefore, there is no need to administer the caution and their statement is admissible.

\subsection{Cases Where Constructive Arrest Suffices before Caution Is Administered}

This category of cases is contrary to the above category as the need for caution statement arises once constructive arrest takes place. In Public Prosecutor v Tan Seow Chuan [1985] 1 MLJ 318, acting on information received, an offence relating to dangerous drugs was being committed, and a team of police raided the house and asked the accused to show them his room. Upon searching the room, the police found certain items which contained a substance which was later analyzed and found to be opium. The accused was charged for drug trafficking under section 39B of the DDA 1952. At the trial, the issue arose as to whether the statements made by the accused were admissible. It was held by Peh Swee Chin J that the accused was under arrest as soon as the police officer showed his authority card and the accused was guarded by a corporal although there were no handcuffs or words of arrest. Since no caution was administered, the accused's statement was inadmissible. The learned judge also made reference to the fact that the police were acting on prior information when they raided the accused's house as opposed to making a routine check without anticipating of finding anything ([1985] 1 MLJ 318, 320).

In Public Prosecutor v Johari Bin Abdul Kadir [1987] 2 CLJ 66, the accused was charged for drug trafficking under section 39B of DDA 1952. The court held that the accused was under arrest when he was taken from the bus to the police station where cannabis was found in a bag opened by the accused. Since no caution was administered as required under section 37A of the DDA 1952, the statements made by the accused were inadmissible.

Moreover, in Public Prosecutor v Rosyatimah bte Neza \& Anor[1989] 1 MLJ 360, acting on information, the police raided a shop house. Upon searching, the police found a bag containing cannabis. When asked by the police as to the ownership of the bag, the first accused replied that it belonged to her boyfriend, the second accused. The issue arose as to whether the first accused was under arrest at the time the statement was made since no caution was administered. Peh Swee Chin J held that the first accused was under arrest when she made the statement that the bag belonged to the second accused after the police found the cannabis in the bag. Since there was no caution, her statement was inadmissible. Datuk Baljit Singh Sidhu made a remark to distinguish Rosyatimah from Lim Kim Ann and Tan Chye Joo as in Rosyatimah, the drugs were discovered before the questions were asked and the answers were given (Datuk Baljit Singh Sidhu, 2015).

The recent case that follows this view is no other but Pendakwa Raya v Muhd Yusuf Bukhari [2010] MLJU 15. Acting on information, the police ambushed a shop house. When the accused left the shop house through the grill, the police packed and hugged him from behind. The police ordered the accused to show them his residence and asked him whether he kept "any barang salah", which the accused told the location of drugs placed in the house to the police. The police thereafter brought the accused back into the shop house towards the location pinpointed by the accused. The police admitted in court that no caution was administered towards the accused. Kamardin Bin Hashim JC found that the accused did not have any chance to escape from the police in that occasion. Furthermore, while the police conducted the raid to arrest a drug trafficker named "Yusuf", the accused had admitted to the police that his name is "Yusuf". This fact shows that the accused is unlikely to or not allowed to leave that place, since he 
is the police's target. Therefore, the learned JC held that constructive arrest had taken place. Due to the absence of caution, the accused's statement that pointed to the location of the drug is inadmissible in court.

On a serious note, the researchers observed from the research that most of the judges prefer the first view which is "actual arrest is required before caution is administered". This is especially after the Federal Court judgment of Public Prosecutorv Lim Hock Boon [2009] 3 MLJ 604. This fact applies to the cases in the category that have been discussed above (Cases Where Actual Arrest Is Required Before Caution Is Administered) and the FCJ held in clear and unequivocal terms that "The need to administer the caution under s 37A of the DDA 1952 only arises after actual arrest and not constructive arrest ([2009] 3 MLJ 604). With that being said, the researchers would like to make an inference that category above has prevailed over Category (Cases where constructive arrest suffices before caution is administered); and the era of this Category has since then been brought to an end. It is noteworthy that while Lim Hock Boon was reported in 2009, the final case in this category (Cases where constructive arrest suffices before caution is administered) Muhd Yusuf Bukhari was reported in 2010 in High Court. This judgment does not follow the principle of stare decisis and go against the principle laid down in the apex court. In the researchers' opinion, this judicial mistake should not ever happen again.

From the case study above, the researchers make this analysis; it is trite law that actual arrest is required before caution is administered in drug cases. In other words, the arrest in Section 37A of the DDA 1952 refers to actual arrest and constructive arrest has no place in the law. If there was no actual arrest, no caution is required and statements made are admissible provided it is relevant. On the contrary, if an actual arrest has been effectuated but caution is not administered, statements made after the arrest is inadmissible.

In the next chapter, the judgment of Mohd Safwan Husain will be analysed based on the law of arrest discussed above.

\section{Case Analysis of Mohd Safwan Husain}

\subsection{Meaning of Arrest under Section 15 of the CPC}

Referring to the judgement of Pendakwa Raya lwn Mohd Safwan Husain[2017] MLRAU 175 the issue raised in this dispute is whether the meaning of "arrested person" in s.31A (1A) of the DDA 1952 is within the scope of "constructive arrest". The main issue discussed in this appeal is the concept of constructive arrest and the meaning of arrested person. Not to forget that the court also formulated a new principle on the meaning of arrested person. The issue that raised from the meaning of arrested person is that when a person is considered as arrested? In our present case, the court explained in detail the meaning of arrested person. In order to answer the primary issue of our present case, the court started off defining "arrest" ([2017] MLRAU 175). In order to determine whether a person is arrested, it is essential for the court to define the meaning of arrest as arrest is a fundamental element in this case. Hence, defining arrest would help in determining the meaning of arrested person.

In our present case, the court referred to Mimi Kamariah Majid in Criminal Procedure in Malaysia (Third Edition) ([2017] MLRAU 175). Mimi Kamariah Majid cited that according to Halsbury's Law of England:

Arrest consists in the seizure or touching of a person's body with a view to his restraint; words may, however, amount to an arrest if, in the circumstances of the case, they are calculated to bring, and do bring, to a person's notice that he is under compulsion and he thereafter submits to the compulsion (Mimi Kamariah, 1999).

Next, the court referred to section 15 of the CPC to determine the mode of arrest took place in this case ([2017] MLRAU 175). In further determining the meaning of arrest, the court in the current case referred to the judgment in Shaaban \& Ors v. Chong Fook Kam \& Anor[1969] 2 MLJ 219. and Holgate-Mohammed v Duke[1984] AC $437(\boldsymbol{H L})$. Nevertheless, the court in Safwan's case held that the most relevant provision in regard to arrest is Section 15 of the CPC. The court observed that the principle of arrest in Shaaban is wide and an arrest is a question of fact to be decided according to the facts of each case. It should be noted that arrest is a continuing act which started with the arrester taking a person into his custody, and continues until the person restrained is either released from custody or, having been brought before a magistrate, is remanded in custody by the magistrate's judicial act (Holgate-Mohammed v. Duke [1984] AC 437 (HL) 441). It can be seen that the court interpreted the meaning of arrest by referring to few decided cases and decided that arrest is not limited to section 15 of CPC.

After determining the meaning of arrest, the court applied the principle of arrest in the present case. The court referred to the general principle used in PP v. Shee Chin Wah [1997] 3 MLRH 500 in determining actual and constructive arrest. ${ }^{59}$ However, the court did not elaborate in detail on the actual arrest and constructive arrest as this case cannot be reconciled ([2017] MLRAU 177). The court further referred to PP v. Abdul Rahim Kalandari Mustan [2017] MLRAU 177 regarding the issue of actual arrest and constructive arrest. In PP v. Abdul Rahim 
Kalandari Mustan, it was held that the words of "actual arrest" and "constructive arrest" is unfortunate because our law only provided for "arrest" which is clear that in order to know whether an arrest has taken place, it should be based on the facts and circumstances of the case. Therefore, the approach used in Safwan's case in determining the arrest was based on the facts and circumstances of the case.

Besides, the prosecution in this case contended that the arrest took place in this case falls under the scope of constructive arrest meanwhile the respondent argued that it was actual arrest ([2017] MLRAU 178). The court refused to follow the approaches mentioned by the counsels as those approaches are hard to reconcile and unfortunate (PP v. Abdul Rahim Kalandari Mustan [2017] MLRAU 178). Instead, the principles of arrest formulated in PPv. Abdul Rahim Kalandari Mustan was applied as it is relevant for the court to determine the issue of arrest based on the facts and circumstances of the case.

\subsection{Meaning of Arrested Person under Section 31 of the DDA 1952}

The meaning of 'an arrested person' under section 31A of the DDA 1952 falls under the scope of 'constructive arrest'. First and foremost, this provision states that only 'an arrested person' could be asked by a police officer (not below the rank of Sergeant) to provide a specimen of his urine for the purpose of an examination by a medical officer as provided for under another subsection, namely subsection (1) of section 31A of the DDA 1952 (Section 31A(1) and (1A) Of Dangerous Drugs Act 1952).

In general, this section also assists the police to proceed with the investigation by providing the validity on their actions especially in conducting inspections on any person who has been arrested. section 31A(1) of the DDA 1952 expressly authorizes the police officer on a given rank, to refer a person who has been arrested to a medical officer or anyone that is permitted for the purpose of inspection.

Furthermore, for the purpose of preservation of evidence, the arrested person is required to provide a specimen of his urine to the police officer for examination under section 31A(1) of the DDA 1952, if it is not practical for the medical officer to obtain the specimen of the urine within a reasonable period. Hence, the intake of the urine is valid.

In the case of Shaaban [1969] $2 \mathbf{M L J}$ 219, the meaning of 'arrested person' under section 31A (1A) of the DDA 1952 on what constitutes a constructive arrest was discussed. In the present case, it was explained by the court that the moment the liberty of the appellant was restrained, and he was compelled to follow the orders given by the police, the appellant was found under immediate arrest. Hence, the appellant in this case was under arrest when he was detained by the police and was ordered to give his urine specimen.

In Safwan's [2017] 5 MLJ 255 case, the court interpreted that the appellant was an arrested person when he was ordered to undergo the urine test. However, the court distinguished section 31A and section 31 of the DDA 1952 and explained that section 31A DDA 1952 does not give the police the authority to arrest a person. Instead, the authority falls under section 31 of the DDA 1952. Section 31A of the DDA 1952 does not provide that the failure to adhere to the said provisions will cause the evidence adduced from the examination to be inadmissible. This is supported by the illustration in the case of Ananth Kumar Naik vs The State of Andhra Pradesh 1977 CriLJ 1797, where examination of a person by medical practitioner includes the examination of his blood, sputum, semen, and urine other than physical examination. Hence, if the blood sample adduced, though unlawfully taken, should be admissible as evidence. In short, the court accepted the blood sample as it is relevant to the facts in issue instead of observing the lawfulness of the evidence adduced. Although the lawfulness of the evidence was challenged in this case, the court opted to follow the general rule that an illegally obtained evidence is admissible as long it is relevant to the facts in issue. However, if there is a non-compliance when the evidence is obtained illegally, the evidence can be challenged in court. Hence, the urine test taken in the present case does not contradict with section 31A (1A) of the DDA 1952.

Based on the analysis of the general principles above, there is sufficient facts and conditions in this case which indicate that at the time the respondent was directed to give his urine specimen, he was already arrested for the purpose of section 31A (1A) of the DDA 1952. Should be noted here that section 31A of the DDA 1952 does not allocate power of arrest to police officers. The authority was granted in section 31 of the DDA 1952. Section 31 of the DDA 1952 gives the power of arrest if there is a reasonable belief that an offence under DDA 1952 has been committed or will be done. This is to justify the submission of information received (information received) by police as evidence to determine this arrest.

\subsection{Meaning of Arrest under Section 37A of the DDA 1952 and the Need to Administer Caution}

Zainun Ali J in PP v Mohd Nor bin Bakar [2000] 2 AMR 2343 observed that section 37A of the DDA 1952 serves two purposes: (a) to assist the prosecution in establishing its case against the accused and (b) to protect the accused 
against the admission of incriminating statements made by him, falsely induced by hope or fear. Section 37A of the DDA 1952 is reminiscent of section 113 of the CPC. The provision provides that a statement made by an accused which is stated either in oral or writing regardless the time he was charged, requires the statement to be made "to or in the hearing of any police officer of or above the rank of Inspector or any senior officer of customs' is admissible provided that the statement is made voluntarily and a caution is administered to a person before he makes a statement (Mimi Kamariah Majid, 1995). This caution must be administered if the statement is taken after the person's arrest. If there is insufficient time to administer a caution, the statement will not be rendered inadmissible in evidence if it is administered as soon as possible thereafter (Mimi Kamariah Majid, 1995).

The issue raised in Safwan was as to when can a statement made by an accused be regarded as admissible? The prosecution contended that the meaning of arrest under section 31A of the DDA 1952 falls within the scope of constructive arrest meanwhile the appellant argued that it falls under the scope of actual arrest. However, the court in Safwan had referred to the case of PP v Lim Hock Boon [2009] 1 MLRA 262. In this case, the issue discussed was whether the statement made by the arrested person is rendered admissible after his arrest although caution had not been administered under section 37A of the DDA 1952. It was interpreted that the moment the defendant's car was turned off and the police took possession of the keys, the defendant was found under immediate arrest. As to when a person can be regarded as being under arrest for the purpose of section 37A of the DDA 1952, it is a question of fact to be decided according to the circumstances of each cases (PP v Kang Ho Soh [1991] 2 MLRH 216.). Therefore, in the case of Lim Hock Boon, YA Abdul Aziz Mohamad FCJ explained that an arrest should be decided based on the "surrounding circumstances". In the present case, the prosecution contended that "the need to administer the caution under section 37A of the DDA 1952 only arises after actual arrest and not constructive arrest". However, the court emphasized that the meaning of arrest should be interpreted according to the circumstances of each cases and followed the approach used by YA Abdul Aziz Mohamad FCJ in the case Lim Hock Boon. This is consistent to our finding in sub-chapter above. This interpretation on arrest is very wide as over the time the interpretation on arrest may vary from case to case.

The second issue raised was whether there arises a need to administer caution? The general principle is that "the need to administer the caution is a question of fact to be decided according to the circumstances of each case" (PP v Lim Hock Boon [2009] 1 MLRA 262). In the judgment of Safwan, the court mentioned that section 37A of the DDA 1952 provides that a statement made by an accused after his arrest does amount to inadmissibility of evidence if caution was not given. The proper administration of the statutory caution is a pre-requisite to admissibility. For the court to be satisfied that the caution has been properly administered there must be evidence by the recording officer that the actual words of the caution were administered or read (Hisyam Abdullah \& Teh Poh Teik, 2006). A bare statement without evidence of the accompanying words of the caution is insufficient and is fatal. Even though the cautioned statement contained the words of the caution it cannot supplement the omission (Hisyam Abdullah \& Teh Poh Teik, 2006). This law is formulated in the case of Francis Anthonysamy v PP[2005] 2 AMR 750 .

If a statement is made without an arrest, then the caution under section 113 of the CPC need not be administered. Equally, statements made under the latter statements are not 'cautioned statements' as understood. They will constitute statements made to the police. In Krishnan [1987] 1 CLJ 28 the Supreme Court had to decide on the admissibility of a statement purportedly made under section 113 of the CPC. It was held that since there was an arrest, the statement made thereafter must be preceded by a caution. As there was none, the statement could not be admitted.

As prescribed in section 37A of the DDA 1952, caution is a requirement. Hence, non- compliance with the requirement would render the statement inadmissible. This can be seen from the case of Wai Chan Leong v Public Prosecutor[1989] 3 MLJ 356 and PP v Rosyatimah bte Neza \& Anor[1989] 1 MLJ 360. Nevertheless, a caution is not necessary if there is no arrest. The issue of whether there is an arrest or not was raised in Jayaraman \& Ors[1982] 2 MLJ 306. In this case, oral statements were made to ASP Jamaluddin but no caution was administered prior to the statements. The statements were somehow sought to be admitted as evidence henceforth the issue of arrest was addressed. The Federal Court held that there was no arrest made and the oral statements made without a caution being administered were admissible.

To sum up, whether a person in a particular case was under actual arrest under section 37A of the DDA 1952 is a question of fact, which is to be decided according to the circumstances of each case (PP v Kang Ho Soh [1991] 2 MLRH 216). Moving on to the next issue which is whether the caution statement is necessary. The court in Safwan referred to the general rule which provides that 'the need to administer caution is a question of fact to be decided according to the circumstances of each case'. 


\section{Conclusion}

Based on the research, there are two forms of arrest which are the actual arrest and the constructive arrest. In order to determine whether an actual arrest had taken place, the court will either look into the statutory conditions enumerated in section 15 or the conditions laid down in Shaaban. Constructive arrest occurs when the court makes an inference based on the facts and circumstances of the case. In the case of Safwan, the court decided that an arrest should be decided based on the facts and circumstances of the case. Moreover, when an actual arrest takes place, it is crucial to administer caution prior to the statements in order to admit them as evidence. When a constructive arrest takes place it is not necessary to administer caution and the statements are admissible as evidence. As mentioned above constructive arrest can take place in various ways.

By way of suggestion, there exists an urgent need to amend the present provision as the definition of arrest under section 15 of Criminal Procedure Code is restricted and narrower than that of Shaaban. In order to overcome this, the principle laid down in the present case should be taken into consideration. The wider interpretation approach applied in this case, inter alia, "determination of the formation of arrest according to the facts and circumstances of the case" shall be codified. To make it clearer and more directive, illustrations of constructive arrest should be listed under the provision as to how would it occur. Besides, explanation on what constitutes a constructive arrest should be provided in the Criminal Procedure Code too as for now there is no governing law on constructive arrest.

\section{Acknowledgement}

Funding: The research is funded by Universiti Kebangsaan Malaysia (UKM). Competing Interests: The authors declare that they have no competing interests.

\section{References}

Alderson v Booth [1969] 2 QB 216.

Ananth Kumar Naik vs The State of Andhra Pradesh [1977] CriLJ 1797.

Anon. (2015). Oxford Dictionary of Law (8th ed.). United Kingdom: Oxford University Press.

Black's Law Dictionary Website. https://thelawdictionary.org/letter/a/page/131/ [16 November 2019].

Criminal Procedure Code Dangerous Drugs Act

Datuk, B. S. S. (2015). Criminal Litigation Process (3rd ed.). Malaysia: Thomson Reuters Malaysia Sdn Bhd.

Francis Antonysamy v Public Prosecutor [2005] 2 CLJ 481.

Hisyam, A., \& The, P. T. (2006). The Law on Drugs Possession and Trafficking in Malaysia.

Holgate-Mohammed v. Duke [1984] AC 437 (HL) 441.

Jayaraman \& ors $v$ PP [1982] 2 MLJ 306.

Jayaraman \& ors v PP [1982] 2 MLJ 306.

Krishnan v Public Prosecutor [1987] 1 CLJ 28. Pendakwa Raya v Kang Ho Soh [1992] 1 MLJ 360. Pendakwa Raya v Keow Sze Teve [2018] MLJU 1571.

Lee, C. F., Habibah, K., \& Che, A. H. (2010). The Process of Criminal Justice Part 1: Investigation and Pre-Trial Proceedings ( $1^{\mathrm{st}}$ ed.). Singapore: Lexis Nexis.

Malaysian Bar. Arrest and Remand. https://www.malaysianbar.org.my/arrest_re mand_.html [16 November 2019]. Masa AK Nangkai \& ors v Sgt Edwin Nancha \& anor [2005] 1 MLJ 581.

Mimi, K. (1995). Dangerous Drugs Law. Michie Butterworth.

Mimi, K. (1999). Criminal Procedure in Malaysia (3rd ed.). Kuala Lumpur: The University Malaya Press.

Pendakwa Raya v Keow Sze Teve [2018] MLJU 1571.

Pendakwa Raya v Mohd Safwan Husain [2017] MLRAU 175.

Pendakwa Raya v Muhd Yusuf Bukhari [2010] MLJU 156.

Polis Diraja Malaysia v Audrey Keong Mei Cheng [1994] 3 MLJ 296.

PP v Abdul Rahim Kalandari Mustan [1998] 5 CLJ 566.

PP v Johari Abdul Kadir [1987] CLJ Rep 889.

PP v Lim Hock Boon [2009] 3 MLJ 604. 
PP v Mohd Nor bin Bakar [2000] 2 AMR 2343.

PP v Rosyatimah bte Neza \& anor [1989] 1 MLJ 360.

PP v Shee Chin Wah [1997] 5 CLJ 472; PP v David Ackowuah Bonsu [1998] 7 MLJ 451.

PP v. Abdul Rahim Kalandari Mustan [2017] MLRAU 178.

Public Prosecutor v David Ackowuah Bonsu [1998] 7 MLJ 451.

Public Prosecutor v Johari Bin Abdul Kadir [1987] 2 CLJ 66.

Public Prosecutor v Lim Hock Boon [2009] 3 MLJ 604.

Public Prosecutor v Lim Kin Ann [1988] 1 MLJ 401.

Public Prosecutor v Rosyatimah bte Neza \& Anor [1989] 1 MLJ 360.

Public Prosecutor v Salleh Bin Saad [1983] 2 MLJ 164.

Public Prosecutorv Tan Chun Cheng \& Anor [2018] 1 LNS 1651.

Public Prosecutor v Tan Chye Joo \& Anor [1988] 1 MLJ 401.

Public Prosecutorv Tan Seow Chuan [1985] 1 MLJ 318.

Public Prosecutor v. Shee Chin Wah [1997] 3 MLRH 500.

$R v$ Inwood [1973] 2 ALL ER 645.

Shaaban v Choong Fook Kam [1969] 2 MLJ 219.

Spicer v Holt [1976] RTR 389.

Wai Chan Leong v Public Prosecutor [1989] 3 MLJ 356.

Yong Moi Sin v Kerajaan Malaysia \& Anor [2000] 1 MLJ 35.

\section{Copyrights}

Copyright for this article is retained by the author(s), with first publication rights granted to the journal.

This is an open-access article distributed under the terms and conditions of the Creative Commons Attribution license (http://creativecommons.org/licenses/by/4.0/). 